\title{
Students' Perceptions on Learning Management Systems of Arabic Learning through Blended Learning Model
}

\author{
R. Taufiqurrochman ${ }^{1 *}$, Imam Muslimin ${ }^{2}$, Imam Rofiki ${ }^{3}$, Joshua Abah ABAH ${ }^{4}$ \\ ${ }^{1}$ Arabic Education Study Program UIN Maulana Malik Ibrahim Malang, Indonesia \\ ${ }^{2}$ Islamic Education Management Study Program UIN Maulana Malik Ibrahim Malang, Indonesia \\ ${ }^{3}$ Mathematics Education Study Program UIN Maulana Malik Ibrahim Malang, Indonesia \\ ${ }^{4}$ Mathematics Education Study Program Federal University of Agriculture Makurdi, Nigeria
}

\section{Article History: \\ Received : November 11, 2019 \\ Revised : December 15, 2019 \\ Accepted : January 25, 2020 \\ Published : June 01, 2020}

\section{Keywords:}

Applications; Grammar; Speaking; Writing

*Correspondence Address: taufiq@uin-malang.ac.id

\begin{abstract}
The emergence of various Learning Management System (LMS) applications support the implementation of Arabic learning with a blended learning model that combines traditional method (face to face) and online. The purpose of this study is to describe students' perceptions as users of the LMS application. The study was descriptive research. As many as 150 students involved in this study, 75 percent chose the blended learning model for learning Arabic. They called the ten most popular LMS application platforms such as Google Classroom, Edmodo, Schoology, Geschool, Our Class, Kelase, ClassDojo, TrackCC, Class123, and Eckovation. Of the 10 LMS applications, the best is Edmodo and the most famous is the Google Classroom. The potential of the LMS application as a representation of the blended learning model is because it has a variety of features. There are at least 16 features, namely: integration of LMS applications with social media, communication features with parents, attendance, payment, homework, conferences, forums, certificates, quiz (polling), document shares, grade books, announcements, testing/surveys, calendar/schedule, email, and chat facilities. The results of students' perceptions regarding these features indicate that they understand all the functions of the LMS features. About learning Arabic, they assessed that all LMS applications had the potential to be used for learning Arabic. The most significant potential is the ability of the LMS application to help learn speaking, writing, and grammar (Sharaf and Nahwu) skills.
\end{abstract}

\section{Introduction}

The development of digital applications in the Industrial Revolution 4.0 era is increasingly rapid. The number of internet users in Indonesia is also increasing. ${ }^{1}$ This is an opportunity for developers to provide a variety of applications for learning, known as the Learning Management System (LMS). Various existing LMS applications, of course,

1 Fitrah Fasyanabilla Lotan, "Making A Positive Internet Through Socmed Agawe Guyub," International Journal Of Communication And Society 1, No. 1 (2019): 9-16. 
aim to improve the quality of education. ${ }^{2}$ These LMS applications also encourage the emergence of a learning model called blended learning or flipped classroom, which is learning that, combines conventional learning models (face to face) and electronics (elearning). ${ }^{3}$

The blended learning model is known to be useful for current learning because it has many advantages, including time efficiency, utilization of the latest technology, unlimited space and time ${ }^{4}$. LMS application developers respond to these advantages by adding various features and facilities needed in learning, such as digital teaching materials, class formation, assignments, quizzes, tests, information sharing and references which can all be done online so that the learning process becomes faster, easier and cheaper. The blended learning model is also believed to apply to a variety of teaching materials, including learning Arabic. ${ }^{5}$ For Muslim communities in Indonesia, Arabic is not a second language, but it is a foreign language. ${ }^{6}$ However, they were enthusiastic about learning Arabic, which was considered as the language of religion, the language of global communication, and international language.

Seeing the relationship between developing diverse LMS applications, applying blended learning models and learning Arabic, it is necessary to know students' perceptions about using LMS applications to learn Arabic with blended learning models. This perception is needed to answer the assumptions that try to inhibit Arabic learning by utilizing LMS applications such as rejection of LMS applications to maintain conventional models. LMS features are considered incomplete and have not been able to

${ }^{2}$ Johan Van Niekerk And Paul Webb, "The Effectiveness Of Brain-Compatible Blended Learning Material In The Teaching Of Programming Logic," Computers \& Education 103 (2016): 16-27; Ezgi Pelin Yildiz And Aytekin Isman, "Quality Content In Distance Education," Universal Journal Of Educational Research 4, No. 12 (2016): 2857-62.

${ }^{3}$ Marcelo C Borba Et Al., "Blended Learning, E-Learning And Mobile Learning In Mathematics Education," Zdm 48, No. 5 (2016): 589-610.

4 Antonia Arnaert Et Al., "Blending Learning: The Preferred Choice Of Clinical Nurse Educators To Provide Continuing Professional Development," Journal Of Nursing Education And Practice 10, No. 1 (2020): 58-66; Lee Yen Chaw And Chun Meng Tang, "What Makes Learning Management Systems Effective For Learning?," Journal Of Educational Technology Systems 47, No. 2 (2018): 152-69; Khetsiwe Eunice Mthethwa-Kunene And Cosmas Maphosa, “An Analysis Of Factors Affecting Utilisation Of Moodle Learning Management System By Open And Distance Learning Students At The University Of Eswatini," Humanities 5, No. 1 (2020): 17-32.

5 Abdelhamid Ahmed And Ahmed Fathy Ibrahim, "Effects And Students' Perspectives Of Blended Learning On English Into Arabic Translation,” Arab Journal Of Applied Linguistics 4, No. 1 (2019): 5080 .

${ }^{6}$ Fithriyah, Usman Kasim, And Yunisrina Qismullah Yusuf, "The Language Learning Strategies Used By Learners Studying Arabic And English As Foreign Languages,” Dirasat: Human And Social Sciences 46, No. 1 (2019): 310-21.

23 | Jurnal Al Bayan: Jurnal Jurusan Pendidikan Bahasa Arab, 12 (1): 22-36 (2020) 
accommodate all needs and learning processes, slow internet networks, lack of facilities, infrastructure and learning media. ${ }^{7}$

According to Aldiab, Chowdhury, Kootsookos, Alam, and Allhibi, LMS is software that can automate the administration of learning. ${ }^{8}$ LMS application can combine conventional learning models and e-learning. ${ }^{9}$ This combination is needed because the concept of e-learning cannot be fully applied online so that blended learning appears. Khalil, Abdel Meguid, and Elkhider define blended learning as described as a mix of traditional face-to-face instruction and e-learning. ${ }^{10}$

From the aspect of ownership authority, LMS applications are divided into two types; self-hosting and vendor-hosting. The LMS self-hosting application is a platform that can be designed and managed as needed. However, this platform requires the role of a reliable administrator in the field of IT, domain rental fees and hosting, localhost, and adequate infrastructure. Whereas vendor-hosting LMS is a platform owned by a third party, ready to use, available menus, cheaper, does not need qualified IT skills, without hosting and domain fees. Still, to use them, it is necessary to analyze needs first to fit the learning process, and objectives blended learning model that wants to be applied. ${ }^{11}$ Therefore, the results of this study are essential for institutions or teachers who want to choose the LMS platform.

The advantages of this LMS support the implementation of the blended learning model in Arabic learning. The blended learning model makes it easier for users to understand the theory and transfer theory into practice. ${ }^{12}$ The blended learning model

${ }^{7}$ Anja Garone Et Al., "Clustering University Teaching Staff Through Utaut: Implications For The Acceptance Of A New Learning Management System," British Journal Of Educational Technology 50, No. 5 (2019): 2466-83.

8 Abdulaziz Aldiab Et Al., "Utilization Of Learning Management Systems (Lmss) In Higher Education System: A Case Review For Saudi Arabia,” Energy Procedia 160 (2019): 731-37.

9 Mohamed Fathima Rashida, "Learning Management System (Lms) In Higher Education Institutions," Journal Of Information System \& Information Technology (Jisit) 2, No. 2 (2018): 15-23.

${ }^{10}$ Mohammed K Khalil, Eiman M Abdel Meguid, And Ihsan A Elkhider, "Teaching Of Anatomical Sciences: A Blended Learning Approach,” Clinical Anatomy 31, No. 3 (2018): 323-29.

${ }^{11}$ R Taufiqurrochman, "Desain E-Learning: Website Based Learning, Classroom Learning, Mobile Learning," In Pembekalan Pedagogik Dosen Uin Malang Oleh Lpm Uin Malang (Malang: Lpm Uin Maulana Malik Ibrahim Malang, 2018), 1-15.

${ }^{12}$ Nimer Alrushiedat And Lorne Olfman, “Aiding Participation And Engagement In A Blended Learning Environment," Journal Of Information Systems Education 24, No. 2 (2019): 133-45; Eirini Dellatola, Thanasis Daradoumis, And Yannis Dimitriadis, "Exploring Students' Engagement Within A Collaborative Inquiry-Based Language Learning Activity In A Blended Environment," In Emerging Technologies And Pedagogies In The Curriculum (Singapore: Springer, 2020), 355-75; Andrew M Blaine, "Interaction And Presence In The Virtual Classroom: An Analysis Of The Perceptions Of Students And Teachers In Online And Blended Advanced Placement Courses," Computers \& Education 132 (2019): 31Jurnal Al Bayan: Jurnal Jurusan Pendidikan Bahasa Arab, 12 (1): 22-36 (2020)| 24 
makes students better prepared for class lessons and improves performance in taking tests. ${ }^{13}$ In its implementation, blended learning does not require online method, but it must be combined with face-to-face methods so that education remains controlled.

Several studies on LMS have been widely studied by experts. Liu, Brantmeier, Wilcox, Griffin, Calcagno-Roach, and Brannon developed the LMS instrument that initially was validated with 243 response sets. ${ }^{14}$ Yuen, Cheng, and Chan investigated the relationship between changes to LMS use and belief, and satisfaction with LMS among 1179 students. ${ }^{15}$ Chaw and Tang explored the effectiveness of LMS in learning. ${ }^{16}$ Stockless inquired the factors that influence the acceptability of the LMS by secondary school teachers. ${ }^{17}$ Rhode, Richter, Gowen, Miller, \& Wills identified various forms of LMS that are frequently used. ${ }^{18}$ De Smet, Valcke, Schellens, De Wever, \& Vanderlinde

43; Timothy Teo Et Al., "Factors That Influence University Students' Intention To Use Moodle: A Study In Macau," Educational Technology Research And Development 67, No. 3 (2019): 749-66.

13 Emine Cab1, "The Impact Of The Flipped Classroom Model On Students' Academic Achievement," International Review Of Research In Open And Distributed Learning 19, No. 3 (2018): 202-21; Jian Chen Et Al., "Blended Learning In Basic Medical Laboratory Courses Improves Medical Students' Abilities In Self-Learning, Understanding, And Problem Solving," Advances In Physiology Education 44, No. 1 (2020): 9-14; Sushama Deshpande And Amit Shesh, "Performance Assessment And Remedies Using Blended Learning For Professional Students," In Computing In Engineering And Technology (Singapore: Springer, 2020), 783-90; Adrian Gepp And Kuldeep Kumar, "How To Improve Teaching Using Blended Learning," In Theoretical And Practical Approaches To Innovation In Higher Education (Pennsylvania, Usa: Igi Global, 2020), 80-90; N S Goedhart Et Al., "The Flipped Classroom: Supporting A Diverse Group Of Students In Their Learning," Learning Environments Research 22, No. 2 (2019): 297-310; Ren-Hung Hwang Et Al., "Improving Learning Achievement In Science Education For Elementary School Students Via Blended Learning," International Journal Of Online Pedagogy And Course Design (Ijopcd) 9, No. 2 (2019): 44-62; Hanan Abdel Samia Mabrouk And Gihan Maher Genedy, "Effectiveness Of Flipped Classrooms Using The Blackboard System In Developing Art Work Skills And Attitudes Of Faculty Of Education Female Students At Jouf University Toward The Use Of Practical Skills," Journal Of Research In Curriculum Instruction And Educational Technology 4, No. 3 (2019): 14161; Renata Pavanelli, "The Flipped Classroom: A Mixed Methods Study Of Academic Performance And Student Perception In Eap Writing Context," International Journal Of Language And Linguistics 5, No. 2 (2018): 16-26; Zamzami Zainuddin, "Students' Learning Performance And Perceived Motivation In Gamified Flipped-Class Instruction," Computers And Education 126 (2018): 75-88, Https://Doi.Org/10.1016/J.Compedu.2018.07.003; Zamzami Zainuddin And Corinne Jacqueline Perera, "Exploring Students' Competence, Autonomy And Relatedness In The Flipped Classroom Pedagogical Model," Journal Of Further And Higher Education 43, No. 1 (2019): 115-26, Https://Doi.Org/10.1080/0309877x.2017.1356916.

${ }^{14}$ Juhong Christie Liu Et Al., "Faculty Perceived Functionality Of Learning Management System: Development And Validation Of A Scale," In Shaping The Future Of Education, Communication And Technology (Singapore: Springer, 2019), 165-77.

15 Allan H.K. Yuen, Miaoting Cheng, And Fred H.F. Chan, "Student Satisfaction With Learning Management Systems: A Growth Model Of Belief And Use," British Journal Of Educational Technology, 2019, 1-16, Https://Doi.Org/10.1111/Bjet.12830.

${ }^{16}$ Chaw And Tang, "What Makes Learning Management Systems Effective For Learning?"

${ }^{17}$ Alain Stockless, "Acceptance Of Learning Management System: The Case Of Secondary School Teachers," Education And Information Technologies 23, No. 3 (2018): 1101-21.

${ }^{18}$ Jason Rhode Et Al., "Understanding Faculty Use Of The Learning Management System," Online Learning 21, No. 3 (2017): 68-86.

25 | Jurnal Al Bayan: Jurnal Jurusan Pendidikan Bahasa Arab, 12 (1): 22-36 (2020) 
conducted qualitative research to investigate the learning path in LMS. ${ }^{19}$ Lakhan and Kumar stated that m-learning activities can much better engage students in the learning process. ${ }^{20}$ Students at online universities have started to accept mobile technology as a new learning tool. ${ }^{21}$ Laisema developed collaborative blended learning activities to improve student collaboration skills. ${ }^{22}$ Although less than a quarter of respondents found blended learning useless, most held positive notions for blended learning practices. ${ }^{23} \mathrm{Di}$, El, Martin, and Gillois reported students' rejection toward LMS that is used for initial training ${ }^{24}$. Al-Sharhan, Al-Hunaiyyan, Alhajri, and Al-Huwail revealed that many universities utilize LMS to improve pedagogy and to increase the quality of online learning. ${ }^{25}$ Our research differs from existing studies because we investigate Arabic university students' perceptions regarding the use of LMS with blended learning.

Based on our observation at Universitas Islam Negeri Maulana Malik Ibrahim Malang, more than $60 \%$ of respondents or users are pesantren graduate students whose experience in using gadgets and e-learning utilization is still minimal. The learning model in pesantren still uses an old pattern that even students are prohibited from using gadgets. As a consequence, Arabic education students are less familiar with LMS applications. The use of LMS applications for Arabic is still relatively new in the learning process, especially for Arabic education students. Whereas LMS applications are very diverse and varied. Therefore, this study aims to investigate the variations of LMS applications that are compatible with Arabic learning and students' perceptions after experiencing a transition from conventional learning models to blended learning. This assumption results in LMS applications not being used massively in the Arabic

${ }^{19}$ Cindy De Smet Et Al., “A Qualitative Study On Learning And Teaching With Learning Paths In A Learning Management System,” Jsse-Journal Of Social Science Education 15, No. 1 (2016): 27-37.

${ }^{20}$ Anjay Lakhan And Laxman Kumar, "Comprehensive Review On Academic Achievement Levels Through M-Learning," I-Manager's Journal On Educational Psychology 13, No. 2 (2019): 49-58.

${ }^{21}$ Won Sug Shin And Minseok Kang, "The Use Of A Mobile Learning Management System At An Online University And Its Effect On Learning Satisfaction And Achievement," International Review Of Research In Open And Distributed Learning 16, No. 3 (2015): 110-30.

22 Sitthichai Laisema, "Development Of Collaborative Blended Learning Activity On Mobile Learning To Enhance Undergraduate Students' Collaboration Skills," Veridian E-Journal, Silpakorn University (Humanities, Social Sciences And Arts) 11, No. 4 (2018): 682-99.

${ }^{23}$ Alev Ateş Çobanoğlu, "Student Teachers' Satisfaction For Blended Learning Via Edmodo Learning Management System,” Behaviour \& Information Technology 37, No. 2 (2018): 133-44.

${ }^{24}$ L Marco Di Et Al., "Blended Learning For French Health Students: Does Acceptance Of A Learning Management System Influence Students' Self-Efficacy?,' Studies In Health Technology And Informatics 264 (2019): 1169-73.

${ }^{25}$ Salah Al-Sharhan Et Al., "Utilization Of Learning Management System (Lms) Among Instructors And Students," In Advances In Electronics Engineering (Singapore: Springer, 2020), 15-23. 
learning process so that the implementation of the blended learning model has not been maximized. By knowing the students' perceptions after they were directly involved in the use of the LMS application, the researchers hope that students' achievement and motivation in learning Arabic with a blended learning model are increasing.

\section{Method}

This research is descriptive qualitative because it aims to determine students' perceptions about various LMS applications after they take Arabic learning that researchers apply to Arabic e-Learning courses and Arabic Learning Technology. Respondents or samples in this study are purposive because the perception they want to know is specifically aimed at students who are learning Arabic and are directly involved in the process of utilizing LMS applications.

The number of respondents was 150 students. They consisted of 120 students in Arabic Language Study Program Universitas Islam Negeri Maulana Malik Ibrahim Malang, 15 students in the Postgraduate Study Program (S2) of Arabic Language at Universitas Islam Negeri Maulana Malik Ibrahim Malang, and 15 students from Arabic Postgraduate Study Program (S2) at IAIN Kediri. These respondents took part in online classes in several classes using different LMS application platforms. Thus, the heterogeneous nature of students and the types of LMS applications that are also diverse is expected to produce objective perceptions about LMS applications that are applied to the blended learning model for learning Arabic.

The data search was carried out with interview, observation and questionnaire techniques which were distributed to students after they had attended one semester of lectures. The data are selected, tabulated and analyzed using qualitative content analysis and statistical calculations. Through a Likert scale, researchers hope to find out the level of students' perceptions of the LMS application, which is applied to Arabic learning and followed directly by the respondents.

\section{Result and Discussion}

\section{Perception of Blended Learning}

Based on the results of the questionnaire distributed to 150 respondents, it is known that 112 students (75\%) chose the blended learning model; 34 respondents (23\%) 
chose the conventional learning model, and four respondents (3\%) said they enjoyed learning online ultimately (fully online).

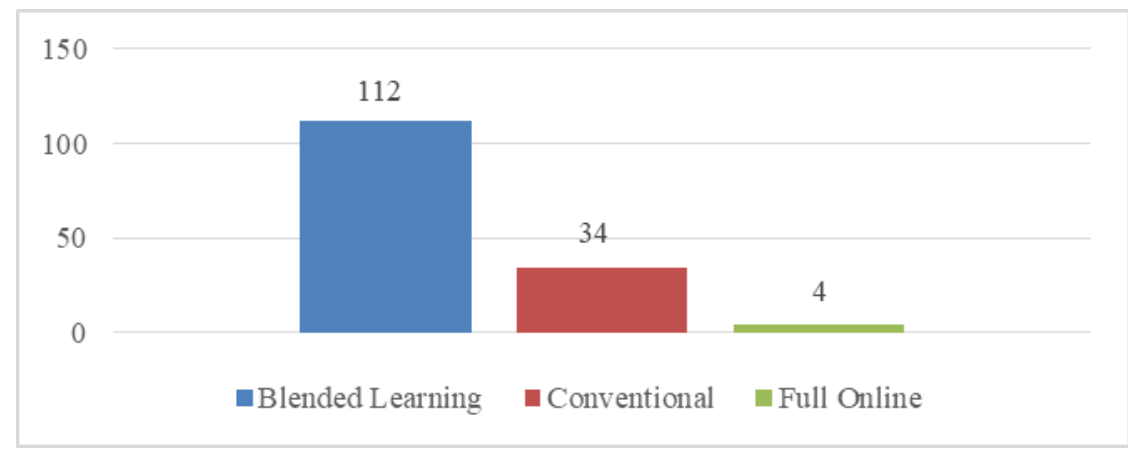

Figure 1. Perception of Blended Learning

The respondents who chose the blended learning model reasoned that blended learning was a necessity. They claim that they use the internet and smartphones every day so that this technology must be used for learning Arabic. Students who choose the conventional model revealed that blended learning will not take place optimally in learning Arabic so that they still need a traditional method (face to face) between lecturers and students. Whereas students who choose full online stated that learning in the digital age should be fully online as an option for students who are busy and may not be present in classroom learning.

As shown in Figure 1, the data also shows that the majority of students (75\%) rated blended learning as a useful learning model for learning Arabic for three reasons. First, the blended learning model implemented through the LMS application is assessed according to learning needs. Second, blended learning integrates conventional models and e-learning so that it is considered more complete. Third, the transformation from traditional to full online does not take place radically to minimize rejection of LMS applications and blended learning models. This is important because direct learning face to face is a culture that has become a tradition in Indonesia so that the LMS application is an effective medium of transformation from conventional to fully online.

\section{Perception about LMS Application}

Based on the results of the questionnaire about the name of the LMS application known to the respondents, there are known ten applications they mentioned, namely: Google Classroom, Edmodo, Schoology, Geschool, Our Class, Kelase, ClassDojo, TrackCC, Class123, Eckovation. Out of the 10 LMS application names mentioned by 150 respondents, researchers asked them to rate the best, most popular, most accessible 
and most appropriate LMS application for learning Arabic. Their answers are summarized in Table 1.

Table 1. Perception about LMS Application

\begin{tabular}{|c|c|c|c|c|c|c|c|c|c|}
\hline \multirow{2}{*}{$\begin{array}{c}\text { No } \\
1\end{array}$} & \multirow{2}{*}{$\begin{array}{c}\text { LMS Application } \\
\text { Google Classroom }\end{array}$} & \multicolumn{2}{|c|}{ Best } & \multicolumn{2}{|c|}{ Most Popular } & \multicolumn{2}{|c|}{ Easiest } & \multicolumn{2}{|c|}{ Most Appropriate } \\
\hline & & 21 & $14 \%$ & 45 & $30 \%$ & 19 & $13 \%$ & 30 & $20 \%$ \\
\hline 2 & Edmodo & 38 & $25 \%$ & 34 & $23 \%$ & 23 & $15 \%$ & 32 & $21 \%$ \\
\hline 3 & Schoology & 27 & $18 \%$ & 24 & $16 \%$ & 21 & $14 \%$ & 23 & $15 \%$ \\
\hline 4 & Geschool & 23 & $15 \%$ & 21 & $14 \%$ & 18 & $12 \%$ & 18 & $12 \%$ \\
\hline 5 & Kelas Kita & 15 & $10 \%$ & 7 & $5 \%$ & 11 & $7 \%$ & 20 & $13 \%$ \\
\hline 6 & Kelase & 9 & $6 \%$ & 6 & $4 \%$ & 12 & $8 \%$ & 13 & $9 \%$ \\
\hline 7 & ClassDojo & 7 & $5 \%$ & 9 & $6 \%$ & 15 & $10 \%$ & 5 & $3 \%$ \\
\hline 8 & TrackCC & 3 & $2 \%$ & 1 & $1 \%$ & 10 & $7 \%$ & 3 & $2 \%$ \\
\hline 9 & Class123 & 4 & $3 \%$ & 2 & $1 \%$ & 13 & $9 \%$ & 5 & $3 \%$ \\
\hline \multirow[t]{2}{*}{10} & Eckovation & 3 & $2 \%$ & 1 & $1 \%$ & 8 & $5 \%$ & 1 & $1 \%$ \\
\hline & Number Of Respondents & 150 & $100 \%$ & 150 & $100 \%$ & 150 & $100 \%$ & 150 & $100 \%$ \\
\hline
\end{tabular}

Table 1 shows that of the 10 LMS applications mentioned by 150 respondents, the best is Edmodo (25\%), the most popular is Google Classroom (30\%), the easiest to use is Edmodo (15\%), and the most appropriate for learning Arabic is Edmodo (21\%). According to respondents, Edmodo is the best, most comfortable and most appropriate LMS application platform for learning Arabic while Google Classroom is rated as the most popular LMS application. Edmodo excellence over other LMS applications because from the beginning, Edmodo has been designed for education. This application consistently improves performance, features and facilities for learning. Nevertheless, Edmodo's popularity is still inferior to Google Classroom. ${ }^{26}$ This is understandable because of Google's support as the largest media company in the world. Google's program, called Google for Education is proof that Google has begun to explore the world of education. ${ }^{27}$ This reality should be considered by competitors to continue to compete. If other platforms do not try to improve performance and create creativity, it is sure to be lost and abandoned by users.

Of the ten most popular LMS applications according to respondents, what's interesting is that there are three Indonesian LMS platforms, namely: Geschool, Our Class and Kelase. These three platforms are at the middle level and can compete with other platforms. The government and users in Indonesia should support the development of domestic product LMS platforms so that the growth of startups and LMS applications

\footnotetext{
${ }^{26}$ Abdullah Saad Alqahtani, “The Use Of Edmodo: Its Impact On Learning And Students' Attitudes Toward It,” Journal Of Information Technology Education 18 (2019): 319-330.

${ }^{27}$ Shampa Iftakhar, "Google Classroom: What Works And How," Journal Of Education And Social Sciences 3, No. 1 (2016): 12-18.

29 | Jurnal Al Bayan: Jurnal Jurusan Pendidikan Bahasa Arab, 12 (1): 22-36 (2020)
} 
is more rapid. Indeed, a large number of internet users in Indonesia is a potential factor for application developers. So, clear regulations and maximum support for Indonesian LMS applications are needed.

\section{Perception of LMS Application Features}

In utilizing the LMS application for learning Arabic, the first and foremost thing is the features or facilities provided by the LMS application. Do users know whether there are Arabic and Indonesian language facilities?

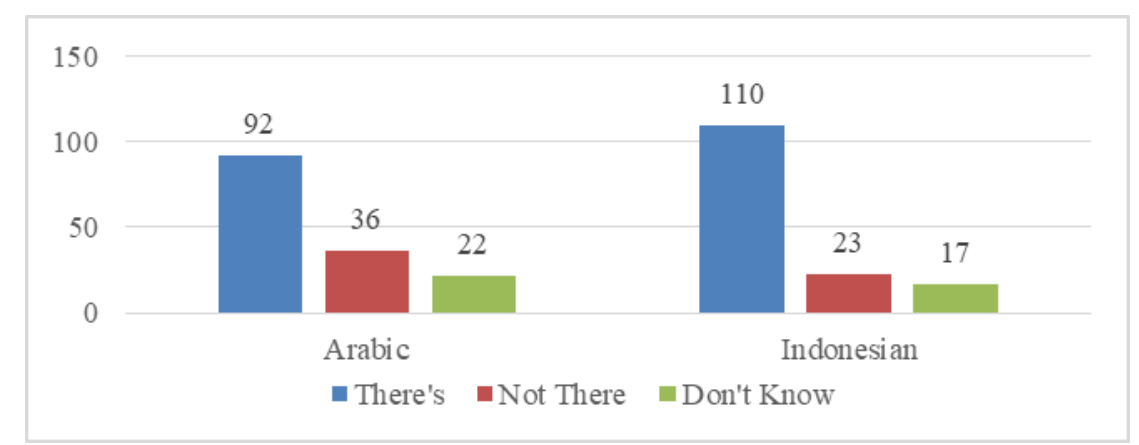

Figure 2. Perception of LMS Application Features

Figure 2 shows 92 people $(61 \%)$ are aware of Arabic features and 110 people (73\%) are aware of Indonesian language features in the LMS application features. According to the user, whether or not the Arabic or Indonesian settings are not a severe problem because the LMS application is still able to be a medium for the whole learning process, especially for communication between users, class management, data storage, and so on.

Table 2. LMS Features

\begin{tabular}{|c|c|c|c|c|c|c|c|c|c|c|c|}
\hline No & LMS Features & 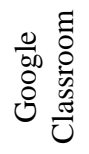 & $\begin{array}{l}8 \\
8 \\
\vdots \\
\Xi \\
I\end{array}$ & $\begin{array}{l}\text { को } \\
\frac{0}{0} \\
0 \\
0 \\
0 \\
0 \\
n\end{array}$ & $\begin{array}{l}\overrightarrow{8} \\
0 \\
0 \\
0 \\
0 \\
0\end{array}$ & 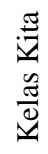 & 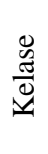 & $\begin{array}{l}\frac{0}{0} \\
\stackrel{0}{0} \\
\frac{0}{0} \\
\text { v }\end{array}$ & 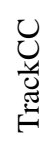 & 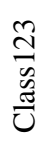 & 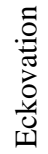 \\
\hline 1 & Social Media & $\sqrt{ }$ & $\sqrt{ }$ & $\sqrt{ }$ & $\sqrt{ }$ & $\sqrt{ }$ & $\sqrt{ }$ & $\sqrt{ }$ & $\sqrt{ }$ & $\sqrt{ }$ & $\sqrt{ }$ \\
\hline 2 & Communication with Parent & & $\sqrt{ }$ & $\sqrt{ }$ & $\sqrt{ }$ & & & $\sqrt{ }$ & & & \\
\hline 3 & Attendance & $\sqrt{ }$ & $\sqrt{ }$ & $\sqrt{ }$ & $\sqrt{ }$ & & & $\sqrt{ }$ & & & \\
\hline 4 & Payment & & $\sqrt{ }$ & $\sqrt{ }$ & $\sqrt{ }$ & $\sqrt{ }$ & $\sqrt{ }$ & & & & \\
\hline 5 & Homework & $\sqrt{ }$ & $\sqrt{ }$ & $\sqrt{ }$ & $\sqrt{ }$ & $\sqrt{ }$ & $\sqrt{ }$ & $\sqrt{ }$ & $\sqrt{ }$ & $\sqrt{ }$ & $\sqrt{ }$ \\
\hline 6 & Conferences & & $\sqrt{ }$ & $\sqrt{ }$ & $\sqrt{ }$ & & & & & & \\
\hline 7 & Forums & $\sqrt{ }$ & $\sqrt{ }$ & $\sqrt{ }$ & $\sqrt{ }$ & $\sqrt{ }$ & $\sqrt{ }$ & $\sqrt{ }$ & $\sqrt{ }$ & $\sqrt{ }$ & $\sqrt{ }$ \\
\hline 8 & Certificates & & $\sqrt{ }$ & $\sqrt{ }$ & & & & & & & \\
\hline 9 & Quizzes (Polls) & $\sqrt{ }$ & $\sqrt{ }$ & $\sqrt{ }$ & $\sqrt{ }$ & $\sqrt{ }$ & $\sqrt{ }$ & $\sqrt{ }$ & $\sqrt{ }$ & $\sqrt{ }$ & \\
\hline 10 & Document Sharing & $\sqrt{ }$ & $\sqrt{ }$ & $\sqrt{ }$ & $\sqrt{ }$ & $\sqrt{ }$ & $\sqrt{ }$ & $\sqrt{ }$ & $\sqrt{ }$ & $\sqrt{ }$ & $\sqrt{ }$ \\
\hline 11 & Books Classes & & $\sqrt{ }$ & & & $\sqrt{ }$ & $\sqrt{ }$ & & & & \\
\hline 12 & Announcements & $\sqrt{ }$ & $\sqrt{ }$ & $\sqrt{ }$ & $\sqrt{ }$ & $\sqrt{ }$ & $\sqrt{ }$ & $\sqrt{ }$ & $\sqrt{ }$ & $\sqrt{ }$ & $\sqrt{ }$ \\
\hline 13 & Testing / Surveys & $\sqrt{ }$ & $\sqrt{ }$ & $\sqrt{ }$ & $\sqrt{ }$ & $\sqrt{ }$ & $\sqrt{ }$ & $\sqrt{ }$ & $\sqrt{ }$ & $\sqrt{ }$ & $\sqrt{ }$ \\
\hline 14 & Calendar / Schedule & $\mathrm{v}$ & $\sqrt{ }$ & $\sqrt{ }$ & $\sqrt{ }$ & $\sqrt{ }$ & & $\sqrt{ }$ & & $\sqrt{ }$ & \\
\hline 15 & E-Mail & $\sqrt{ }$ & & & & & & & & & \\
\hline 16 & Chat Facilities & $\sqrt{ }$ & $\sqrt{ }$ & $\sqrt{ }$ & $\sqrt{ }$ & $\sqrt{ }$ & $\sqrt{ }$ & $\sqrt{ }$ & $\sqrt{ }$ & $\sqrt{ }$ & $\sqrt{ }$ \\
\hline
\end{tabular}


Table 2 mentions 16 features commonly found in LMS applications, namely: integration of LMS with Social Media, communication features with parents, attendance, payment, homework, conferences, forums, certificates, quizzes (polls), document sharing, books classes, announcements, testing/surveys, calendar/schedule, e-mail and chat facilities. Of these 16 features, according to the majority of users, almost all features already exist in the LMS application. They know this feature and claim to be able to operate it efficiently. They contended that LMS features were more than enough to help the Arabic learning process with a blended learning model.

\section{Perception of the Potential of LMS for Learning Arabic}

What are the potential applications of the LMS in accommodating Arabic learning, especially for learning four language skills (listening, speaking, reading, writing) and three language elements (sounds, words, sentences)?

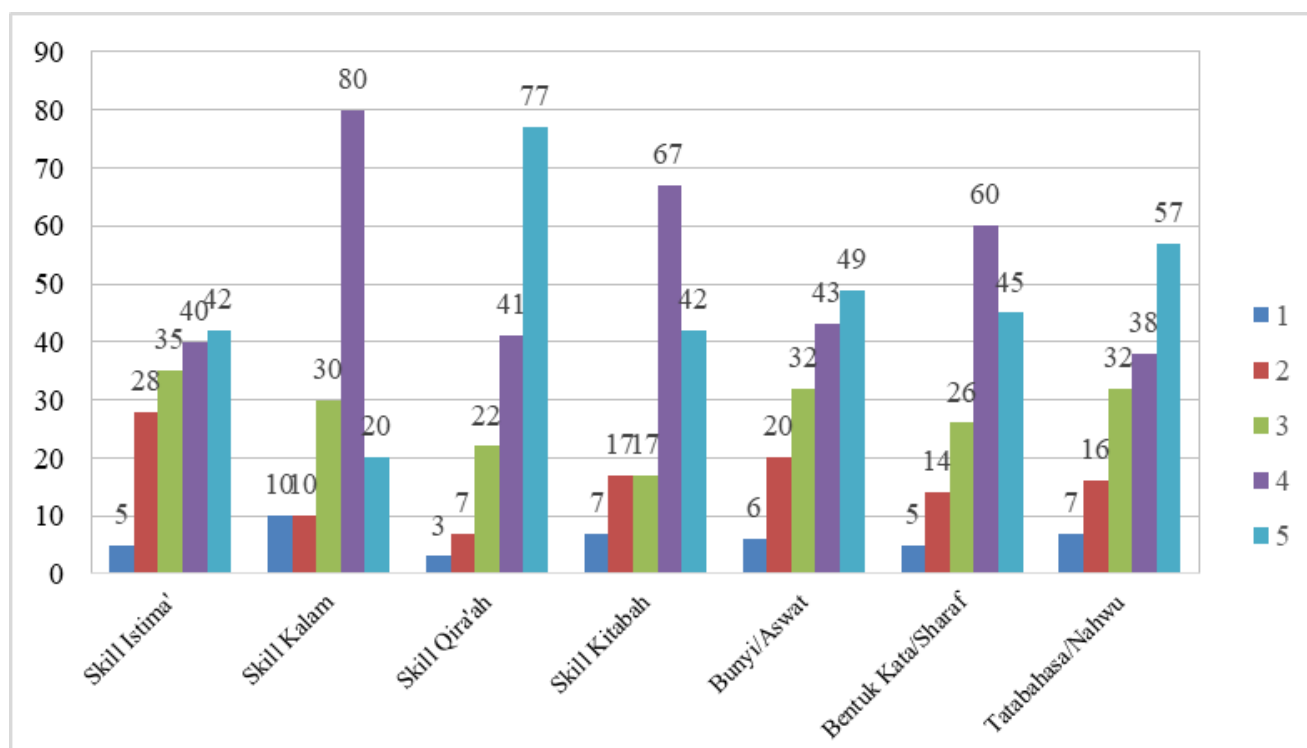

Figure 3. Perception about the Potential of LMS for Learning Arabic

Note: (1) Very Potential; (2) Not Potential; (3) Sufficient Potential; (4) Potential; (5) Very Potential.

Figure 3 shows that the most potential that LMS applications have is for learning the skills of speaking (kalam) and reading (qira'ah). This means that the problem of learning speaking skills and the lack of literacy skills can be overcome by using LMS applications. According to the user, the LMS application contains audio-visuals that are needed to improve speaking skills. In addition, the use of hardware such as mobile phones that contain LMS applications also helps users practice reading skills because almost every time they claim to use mobile phones as learning media. This finding is in 31 | Jurnal Al Bayan: Jurnal Jurusan Pendidikan Bahasa Arab, 12 (1): 22-36 (2020) 
line with the result of the existing studies, which reported that LMS applications could help students to understand and enhance reading skills. ${ }^{28}$

Figure 3 also shows that the LMS application has great potential to help users learn Arabic grammar (Sharaf and Nahwu) which has been challenging to discover with conventional models due to the lack of teacher and student interaction. With the LMS application, communication between teacher and student can take place without being limited by space and time so that students have many opportunities to deepen Arabic elements.

\section{Conclusion}

LMS applications support the implementation of the blended learning model in Arabic learning. The assumptions that so far rejected the blended learning model because it was considered unable to replace the traditional model were incorrect because the features available in the LMS application helped the learning process. This is evidenced by the results of students' perceptions as users of the LMS application. As many as 112 out of 150 students $(75 \%)$ chose blended learning because this model is now able to be realized through various LMS application platforms. Students stated that, of the 10 LMS applications, the most famous is Google Classroom, and the best is Edmodo. Students' perceptions about the features of LMS applications indicate that LMS applications help students to learn and develop their skills in speaking, writing, and grammar (Sharaf and Nahwu). For the next study, it is crucial to investigate the effectiveness of LMS application using blended learning to develop students' higher-order thinking skills. Also, it is needed to examine the impact of blended learning on students' motivation and achievement.

\section{Acknowledgment}

This study is supported by Kementerian Agama Republik Indonesia for funding support of the research project. The authors would like to express our gratitude to Universitas Islam Negeri Maulana Malik Ibrahim Malang, especially the head of the

${ }^{28}$ Yusuf Hanafi Et Al., "Student's And Instructor's Perception Toward The Effectiveness Of E-Bbq Enhances Al-Qur'an Reading Ability,” International Journal Of Instruction 12, No. 3 (2019): 51-68, Https://Doi.Org/10.29333/Iji.2019.1234a; T. Shimauchi, H. Nambo, And H. Kimura, "Proposal For Lms- 
Arabic Education department, for the opportunity provided to the authors to carry out this research.

\section{References}

Ahmed, Abdelhamid, and Ahmed Fathy Ibrahim. "Effects and Students' Perspectives of Blended Learning on English into Arabic Translation." Arab Journal of Applied Linguistics 4, no. 1 (2019): 50-80.

Al-Sharhan, Salah, Ahmed Al-Hunaiyyan, Rana Alhajri, and Nabeil Al-Huwail. "Utilization of Learning Management System (LMS) among Instructors and Students." In Advances in Electronics Engineering, 15-23. Singapore: Springer, 2020.

Aldiab, Abdulaziz, Harun Chowdhury, Alex Kootsookos, Firoz Alam, and Hamed Allhibi. "Utilization of Learning Management Systems (LMSs) in Higher Education System: A Case Review for Saudi Arabia." Energy Procedia 160 (2019): 731-37.

Alqahtani, Abdullah Saad. "The Use of Edmodo: Its Impact on Learning and Students' Attitudes toward It." Journal of Information Technology Education 18 (2019): 319330.

Alrushiedat, Nimer, and Lorne Olfman. "Aiding Participation and Engagement in a Blended Learning Environment." Journal of Information Systems Education 24, no. 2 (2019): 133-45.

Arnaert, Antonia, Hamza Ahmad, Norma Ponzoni, Catherine Oliver, and Adriana Grugel-Park. "Blending Learning: The Preferred Choice of Clinical Nurse Educators to Provide Continuing Professional Development." Journal of Nursing Education and Practice 10, no. 1 (2020): 58-66.

Ateş Çobanoğlu, Alev. "Student Teachers' Satisfaction for Blended Learning via Edmodo Learning Management System." Behaviour \& Information Technology 37, no. 2 (2018): 133-44.

Blaine, Andrew M. "Interaction and Presence in the Virtual Classroom: An Analysis of the Perceptions of Students and Teachers in Online and Blended Advanced Placement Courses." Computers \& Education 132 (2019): 31-43.

Borba, Marcelo C, Petek Askar, Johann Engelbrecht, George Gadanidis, Salvador Llinares, and Mario Sánchez Aguilar. "Blended Learning, e-Learning and Mobile Learning in Mathematics Education.” ZDM 48, no. 5 (2016): 589-610.

Cab1, Emine. "The Impact of the Flipped Classroom Model on Students' Academic Achievement." International Review of Research in Open and Distributed Learning

Like Environment By Utilizing Google Apps To Promote English Reading Activities," Studies In Science And Technology 8, No. 1 (2019): 39-44, Https://Doi.Org/10.11425/Sst.8.39. 
19, no. 3 (2018): 202-21.

Chaw, Lee Yen, and Chun Meng Tang. "What Makes Learning Management Systems Effective for Learning?" Journal of Educational Technology Systems 47, no. 2 (2018): 152-69.

Chen, Jian, Junhai Zhou, Yong Wang, Guangying Qi, Chunbo Xia, Gang Mo, and Zhiyong Zhang. "Blended Learning in Basic Medical Laboratory Courses Improves Medical Students' Abilities in Self-Learning, Understanding, and Problem Solving." Advances in Physiology Education 44, no. 1 (2020): 9-14.

Dellatola, Eirini, Thanasis Daradoumis, and Yannis Dimitriadis. "Exploring Students' Engagement within a Collaborative Inquiry-Based Language Learning Activity in a Blended Environment." In Emerging Technologies and Pedagogies in the Curriculum, 355-75. Singapore: Springer, 2020.

Deshpande, Sushama, and Amit Shesh. "Performance Assessment and Remedies Using Blended Learning for Professional Students." In Computing in Engineering and Technology, 783-90. Singapore: Springer, 2020.

Di, L Marco, H Kechaï El, Donald K Martin, and Pierre Gillois. "Blended Learning for French Health Students: Does Acceptance of a Learning Management System Influence Students' Self-Efficacy?" Studies in Health Technology and Informatics 264 (2019): 1169-73.

Fithriyah, Usman Kasim, and Yunisrina Qismullah Yusuf. "The Language Learning Strategies Used by Learners Studying Arabic and English as Foreign Languages." Dirasat: Human and Social Sciences 46, no. 1 (2019): 310-21.

Garone, Anja, Bram Pynoo, Jo Tondeur, Celine Cocquyt, Silke Vanslambrouck, Bram Bruggeman, and Katrien Struyven. "Clustering University Teaching Staff through UTAUT: Implications for the Acceptance of a New Learning Management System." British Journal of Educational Technology 50, no. 5 (2019): 2466-83.

Gepp, Adrian, and Kuldeep Kumar. "How to Improve Teaching Using Blended Learning." In Theoretical and Practical Approaches to Innovation in Higher Education, 80-90. Pennsylvania, USA: IGI Global, 2020.

Goedhart, N S, N Blignaut-van Westrhenen, C Moser, and M B M Zweekhorst. "The Flipped Classroom: Supporting a Diverse Group of Students in Their Learning." Learning Environments Research 22, no. 2 (2019): 297-310.

Hanafi, Yusuf, Nurul Murtadho, M. Alifudin Ikhsan, Tsania Nur Diyana, and Achmad Sultoni. "Student's and Instructor's Perception toward the Effectiveness of E-BBQ Enhances Al-Qur'an Reading Ability." International Journal of Instruction 12, no. 3 (2019): 51-68. https://doi.org/10.29333/iji.2019.1234a.

Hwang, Ren-Hung, Hsin-Tung Lin, Jerry Chih-Yuan Sun, and Jang-Jiin Wu. "Improving Learning Achievement in Science Education for Elementary School Students via 
Blended Learning." International Journal of Online Pedagogy and Course Design (IJOPCD) 9, no. 2 (2019): 44-62.

Iftakhar, Shampa. "Google Classroom: What Works and How." Journal of Education and Social Sciences 3, no. 1 (2016): 12-18.

Khalil, Mohammed K, Eiman M Abdel Meguid, and Ihsan A Elkhider. "Teaching of Anatomical Sciences: A Blended Learning Approach." Clinical Anatomy 31, no. 3 (2018): 323-29.

Laisema, Sitthichai. "Development of Collaborative Blended Learning Activity on Mobile Learning to Enhance Undergraduate Students' Collaboration Skills." Veridian E-Journal, Silpakorn University (Humanities, Social Sciences and Arts) 11, no. 4 (2018): 682-99.

Lakhan, Anjay, and Laxman Kumar. "Comprehensive Review on Academic Achievement Levels through M-Learning." I-Manager's Journal on Educational Psychology 13, no. 2 (2019): 49-58.

Liu, Juhong Christie, Noorie Brantmeier, Diane Wilcox, Oris Griffin, Jamie CalcagnoRoach, and Rebecca Brannon. "Faculty Perceived Functionality of Learning Management System: Development and Validation of a Scale." In Shaping the Future of Education, Communication and Technology, 165-77. Singapore: Springer, 2019.

Lotan, Fitrah Fasyanabilla. "Making a Positive Internet through Socmed Agawe Guyub." International Journal of Communication and Society 1, no. 1 (2019): 9-16.

Mabrouk, Hanan Abdel Samia, and Gihan Maher Genedy. "Effectiveness of Flipped Classrooms Using the Blackboard System in Developing Art Work Skills and Attitudes of Faculty of Education Female Students at Jouf University toward the Use of Practical Skills." Journal of Research in Curriculum Instruction and Educational Technology 4, no. 3 (2019): 141-61.

Mthethwa-Kunene, Khetsiwe Eunice, and Cosmas Maphosa. "An Analysis of Factors Affecting Utilisation of Moodle Learning Management System by Open and Distance Learning Students at the University of Eswatini." Humanities 5, no. 1 (2020): 17-32.

Niekerk, Johan Van, and Paul Webb. "The Effectiveness of Brain-Compatible Blended Learning Material in the Teaching of Programming Logic." Computers \& Education 103 (2016): 16-27.

Pavanelli, Renata. "The Flipped Classroom: A Mixed Methods Study of Academic Performance and Student Perception in EAP Writing Context." International Journal of Language and Linguistics 5, no. 2 (2018): 16-26.

Rashida, Mohamed Fathima. "Learning Management System (LMS) in Higher Education Institutions." Journal of Information System \& Information Technology (JISIT) 2, 
no. 2 (2018): 15-23.

Rhode, Jason, Stephanie Richter, Peter Gowen, Tracy Miller, and Cameron Wills. "Understanding Faculty Use of the Learning Management System." Online Learning 21, no. 3 (2017): 68-86.

Shimauchi, T., H. Nambo, and H. Kimura. "Proposal for LMS-like Environment by Utilizing Google Apps to Promote English Reading Activities." Studies in Science and Technology 8, no. 1 (2019): 39-44. https://doi.org/10.11425/sst.8.39.

Shin, Won Sug, and Minseok Kang. "The Use of a Mobile Learning Management System at an Online University and Its Effect on Learning Satisfaction and Achievement." International Review of Research in Open and Distributed Learning 16, no. 3 (2015): 110-30.

Smet, Cindy De, Martin Valcke, Tammy Schellens, Bram De Wever, and Ruben Vanderlinde. "A Qualitative Study on Learning and Teaching with Learning Paths in a Learning Management System.” JSSE-Journal of Social Science Education 15, no. 1 (2016): 27-37.

Stockless, Alain. "Acceptance of Learning Management System: The Case of Secondary School Teachers." Education and Information Technologies 23, no. 3 (2018): 1101 21.

Taufiqurrochman, R. "Desain E-Learning: Website Based Learning, Classroom Learning, Mobile Learning." In Pembekalan Pedagogik Dosen UIN Malang Oleh LPM UIN Malang, 1-15. Malang: LPM UIN Maulana Malik Ibrahim Malang, 2018.

Teo, Timothy, Mingming Zhou, Andy Chun Wai Fan, and Fang Huang. "Factors That Influence University Students' Intention to Use Moodle: A Study in Macau." Educational Technology Research and Development 67, no. 3 (2019): 749-66.

Yildiz, Ezgi Pelin, and Aytekin Isman. "Quality Content in Distance Education." Universal Journal of Educational Research 4, no. 12 (2016): 2857-62.

Yuen, Allan H.K., Miaoting Cheng, and Fred H.F. Chan. "Student Satisfaction with Learning Management Systems: A Growth Model of Belief and Use." British Journal of Educational Technology, 2019, 1-16. https://doi.org/10.1111/bjet.12830.

Zainuddin, Zamzami. "Students' Learning Performance and Perceived Motivation in Gamified Flipped-Class Instruction." Computers and Education 126 (2018): 75-88. https://doi.org/10.1016/j.compedu.2018.07.003.

Zainuddin, Zamzami, and Corinne Jacqueline Perera. "Exploring Students' Competence, Autonomy and Relatedness in the Flipped Classroom Pedagogical Model." Journal of Further and Higher Education 43, no. 1 (2019): 115-26. https://doi.org/10.1080/0309877X.2017.1356916. 